\title{
A Study on the Improvement of Real Estate Education System by Changing the Real Estate Industry Environment
}

\author{
[Jaehwan, Kim]
}

\begin{abstract}
Changes in the real estate industry environment are changing rapidly. This means that the competencies and roles required for real estate professionals are being strengthened. However, the current curriculum of the university does not satisfy the curriculum required by the real estate industry. Therefore, we want to develop customized education curriculum for redevelopment sector by using job analysis method. The DACUM technique is used to develop methodologies and extract training objectives and training content in a relatively short time. Jobs consisted of five properties, real estate brokering, real estate management, real estate finance and investment, and real estate development.
\end{abstract}

Keywords-Real Estate Curriculum, DACUM, Job Analysis, Job Model, Real Estate Industry.

\section{Introduction}

After the global financial crisis, the demand for industrial manpower in Korea dropped sharply. In particular, the real estate industry requires people with a focus on theoretical and on-site skills. Thus, universities are required to improve their timely curriculum. In particular, the mass production of experts in the real estate sector is concentrated in universities. In order to meet the needs of these markets, it is necessary to organize education with a focus on practical training for a limited period of time. It is also necessary to have a curriculum that can accurately understand and apply the training programs required by practitioners. Therefore, this study aims to develop a customized curriculum that meets the needs of real estate professionals through the DACUM method.

\section{Related Researches}

Studies on job analysis have been focused on conceptual discussions, vocational education and training courses, and specific academic studies to practice them. In this study, we studied the general research on job analysis, the study on vocational education, and the study on its application. The purpose of this study is to improve the problems of real estate qualification system and to find ways to improve them. In particular, it is aimed at establishing a new qualification system, linking qualifications with educational systems. The purpose of this study is to identify the current status and problems of the system and to utilize it as basic data for solving them. The following procedure was followed. First, various discussions about job analysis itself have been done since the past.

Kongju National University

Republic of Korea
In order for a member of society to participate in the social structure, he or she has to professionally carry out his / her job and define the tasks performed by such individuals as his job. , "Improvement of Job Analysis Guidelines for Vocational Education and Training Program Development", Korea Institute of Vocational Education and (Training, 2005, pp. 32-35). This definition of job defines the concept of many scholars from the division of labor in the production process in order to improve the productivity as claimed by Adam Smith in 1779 . The job analysis is defined as a method of examining the basic requirements of Jeong Duk-moo, and the process of discovering and describing the facts about individual duties is a process of examining the content of work, procedures, responsibilities, qualifications of the practitioner This paper focuses on the relation-ship between job and person and analyzes the job analysis and collects the data describing the observable job of the worker and analyzes the job environment including the physical, mechanical, social, It is defined as an activity that collects data describing verifiable characteristics. In order for successful training to be implemented at the individual or organizational level, a systematic approach to analysis, design, development, implementation, and evaluation is needed in the planning and operation of training programs. In particular, the analysis of the needs of the analysis stage has a significant impact on the design and development of the training program. In the past, the analysis of needs in various organizations including companies was carried out by the trainers and trainers. The contents of actual education and training are not only high possibility that the subjects are different from the job content that they are performing in the actual work, It has become a fundamental cause of degradation. In order to solve these problems, a systematic education and training program design model and methodology have been developed. The results of this study are as follows. First, the analysis of job satisfaction of real estate sector showed the factors of job satisfaction of brokerage firms of real estate brokers. Factors influencing job satisfaction were variables on job characteristics, variables on government management (government policy) And the resultant variables included absentee-ism and turnover. In order to improve the real estate industry and develop the real estate brokerage system for the protection of the consumers through the improvement of the qualifications system for real estate agents, the development of real estate professionals, and the introduction of the real estate brokerage service industry, , Which provides guidance on the behavioral duties of real estate brokers such as securing reliability by clients. This study, however, is not merely an outline of the duties of the real estate brokerage business through job analysis techniques, but merely summarizes the results of the simple questionnaire survey. 
Proc. of The Eighth Intl. Conf. On Advances In Economics, Social Science and Human Behaviour Study - ESSHBS 2018 Copyright (C) Institute of Research Engineers and Doctors, USA. All rights reserved.

ISBN: 978-1-63248-156-6 doi: 10.15224/978-1-63248-156-6-21

\section{Method Analysis}

The previous study on job satisfaction also focuses on the professional satisfaction of brokers. The general scope of job design and derivation needs to be extended to the extent of the study.

Therefore, this study aims to expand the scope of the study to real estate education curriculum and to design and analyze the job of the real estate curriculum in order to contain the contents of actual education and training required in the field. Through this, we aim to provide practical education focused on opinions of the field and provide implications for future major curriculum design. In this respect, this study is different from previous studies.

\section{Procedure of DACUM}

The DACUM method is to classify a job as an element of a task, work, or work by establishing a task-oriented characteristic of a specific job, a required component for performing a job and confirming necessary qualification requirements. The DACUM analysis process of this study proceeded to three stages of DACUM committee composition, job analysis, and demand analysis.

\section{Composition of DACUM Committee}

Five professors of real estate department who have experience in job development among real estate experts, one person in real estate development business, one appraisal appraiser who is qualified in domestic appraisal, one appraiser in overseas appraisal and brokerage, land and house A panel of committee members, including one researcher, one real estate finance and investment practitioner, one real estate consulting worker, and one LH corporation with experience in housing and housing development projects. Nine DACUM committees were formed.

\section{Step 1: Questionnaire for job creation}

In order to derive jobs, I conducted a demand survey on industry and students (students and graduates). First of all, to analyze the needs of the industry, we established mutual cooperation system through industry field survey (more than 5 real estate related companies) through the MOU with industry, and appointed a committee member for the development of the curriculum of the real estate department and the industrial curriculum. In addition, two curriculum development conferences were held (A. The first curriculum development meeting: meeting for the purpose of deriving the personnel-centered job in industry, B. The second curriculum development meeting: And the implementation of the final curriculum council (the Third Curriculum Development Conference: the Human Resources Centered Curriculum Council)
TABLE I. CLASSIFICATION OF REAL ESTATE BUSINESS

\begin{tabular}{|c|c|c|c|}
\hline $\begin{array}{c}\text { Major } \\
\text { occupational } \\
\text { groups }\end{array}$ & $\begin{array}{c}\text { Primary } \\
\text { classification }\end{array}$ & $\begin{array}{c}\text { Secondary } \\
\text { classification }\end{array}$ & $\begin{array}{c}\text { Third } \\
\text { classification }\end{array}$ \\
\hline \multirow{10}{*}{$\begin{array}{l}\text { Real estate } \\
\text { planning } \\
\text { common, } \\
\text { brokerage, } \\
\text { management, } \\
\text { finance and } \\
\text { investment, } \\
\text { development }\end{array}$} & $\begin{array}{l}\text { Real estate } \\
\text { Planning }\end{array}$ & $\begin{array}{l}\text { Real estate } \\
\text { survey }\end{array}$ & $\begin{array}{c}\text { Real estate } \\
\text { development } \\
\text { planning }\end{array}$ \\
\hline & $\begin{array}{l}\text { Real estate } \\
\text { Common }\end{array}$ & \multirow{2}{*}{$\begin{array}{l}\text { Real estate } \\
\text { Sales, } \\
\text { Brokerage }\end{array}$} & Real estate sales \\
\hline & $\begin{array}{l}\text { Real estate } \\
\text { brokerage }\end{array}$ & & $\begin{array}{l}\text { Real estate } \\
\text { brokerage }\end{array}$ \\
\hline & \multirow{3}{*}{$\begin{array}{l}\text { Real estate } \\
\text { Management }\end{array}$} & \multirow{3}{*}{$\begin{array}{c}\text { Real estate } \\
\text { Portfolio }\end{array}$} & $\begin{array}{c}\text { Real estate asset } \\
\text { management }\end{array}$ \\
\hline & & & $\begin{array}{c}\text { Property } \\
\text { management }\end{array}$ \\
\hline & & & $\begin{array}{c}\text { Facility } \\
\text { management }\end{array}$ \\
\hline & \multirow{2}{*}{$\begin{array}{l}\text { Real estate } \\
\text { finance and } \\
\text { investment }\end{array}$} & \multirow{2}{*}{$\begin{array}{c}\text { Real estate } \\
\text { development } \\
\text { finance }\end{array}$} & $\begin{array}{c}\text { Real estate trust, } \\
\text { guarantee }\end{array}$ \\
\hline & & & $\begin{array}{l}\text { REITs, Funds, } \\
\text { Indirect } \\
\text { investment } \\
\text { products }\end{array}$ \\
\hline & \multirow{2}{*}{$\begin{array}{c}\text { Real estate } \\
\text { development }\end{array}$} & \multirow{2}{*}{$\begin{array}{c}\text { Real estate } \\
\text { market } \\
\text { analysis }\end{array}$} & $\begin{array}{l}\text { Real estate } \\
\text { consulting }\end{array}$ \\
\hline & & & Land survey \\
\hline
\end{tabular}

\section{Step 2: Core Job Classification by Requirements Analysis}

The classification of occupation was selected as a major occupational group by the analysis of relevant industry referring to the Ministry of Labor 's labor, the real estate business law which is related to the real estate business law, and experts' common real estate, brokerage, management, finance, investment and development. First, classified as the first six categories of real estate planning, real estate common, real estate brokerage, real estate management, real estate finance and investment, and real estate development. In addition, real estate research, real estate planning, real estate sales, and intermediary real estate PM are categorized into real estate AM and real estate FM by the second category. Real estate finance and investment are divided into the second category of real estate development finance and the real estate trust and REIT. 
Proc. of The Eighth Intl. Conf. On Advances In Economics, Social Science and Human Behaviour Study - ESSHBS 2018 Copyright (C) Institute of Research Engineers and Doctors, USA. All rights reserved.

ISBN: 978-1-63248-156-6 doi: 10.15224/978-1-63248-156-6-21

TABLE II. CLASSIFICATION ACCORDING TO JOB MODEL

\begin{tabular}{|c|c|c|}
\hline Job & Duty & Task \\
\hline Real estate in commons & $\begin{array}{l}\text { A. Real estate } \\
\text { planning }\end{array}$ & $\begin{array}{l}\text { A1. Understand the characteristics of real estate good } \\
\text { A2. Understanding the legal basis of real estate } \\
\text { A3. Understanding the technical basics of real estate } \\
\text { A4. Basic understanding of investment and financial analysis of real estate } \\
\text { A5. Basic understanding of evaluation methods of real estate } \\
\text { A6. Understanding the transaction basics of real estate } \\
\text { A7. Employment skills development }\end{array}$ \\
\hline Real estate brokerage & $\begin{array}{l}\text { B. Real estate } \\
\text { contract }\end{array}$ & $\begin{array}{l}\text { B1. Understanding of the securities and bond law } \\
\text { B2. Understanding the characteristics and systems of brokerage } \\
\text { B3. Understanding real estate appraisal and pricing practice } \\
\text { B4. Understanding contract writing } \\
\text { B5. Understand the brokerage office establishment registration } \\
\text { B6. Real estate transaction declaration and understanding of tax practice } \\
\text { B7. Cultivation of major foreign language and kanji skills }\end{array}$ \\
\hline Property management & $\begin{array}{l}\text { C. Real estate } \\
\text { Management }\end{array}$ & $\begin{array}{l}\text { C1. Understanding aspects of property management } \\
\mathrm{C} 2 \text {. Understanding facility management (FM) } \\
\text { C3. Understanding property management (PM) } \\
\text { C4. Understanding asset management (AM) }\end{array}$ \\
\hline Real estate finance and investment & $\begin{array}{c}\text { D. Real estate } \\
\text { decision making }\end{array}$ & $\begin{array}{l}\text { D1. Understanding of finance and investment theory } \\
\text { D2. Understanding the legal characteristics of real estate development finance } \\
\text { D3. Understanding of investment and housing finance } \\
\text { D4. Understanding commercial property finance } \\
\text { D5. Understanding project financing and REITs } \\
\text { D6. Understanding real estate finance and investment consulting practice }\end{array}$ \\
\hline Real estate development & $\begin{array}{l}\text { E. Property } \\
\text { supply \& } \\
\text { demand }\end{array}$ & $\begin{array}{l}\text { E1. Understanding real estate Market analysis } \\
\text { E2. Understanding land development process step by step } \\
\text { E3. Understanding real estate site, architecture, and development analysis } \\
\text { E4. Understanding and use regulation system and development planning act } \\
\text { E5. Understanding real estate marketing strategy } \\
\text { E6. Understanding land and housing policy }\end{array}$ \\
\hline
\end{tabular}

\section{Results}

The following are the key roles that have been derived for the tasks of real estate common, real estate brokerage, real estate management, real estate finance and investment, and real estate development. First of all, the common role of real estate is defined as a common work scope such as real estate legal counseling, real estate technical counseling, and real estate transaction counseling, which is a comprehensive business scope for real estate transaction contracts that are essential for real estate business. The role of real estate brokerage is to represent and negotiate the sale, lease, and ex-change of real estate such as buildings, land, houses, and apartments, receive commission on behalf of both real estate brokers, collect information about land price and real estate, It is defined as the task of adjusting and contracting the price. The role of real estate management is defined as physical management, asset management, and facility management of investors' real estate business, which is responsible for all kinds of administrative tasks required for real estate business. The role of real estate financing and investment is to use real estate financing and real estate financing, including stock and bond reports, economic forecasts, volumes, financial journals, corporate financial statements and other financial and financial reports and publications, It is defined as the task of analyzing investment information and providing information. Finally, the role of real estate development is de-fined as the task of managing the entire process from the planning stage to the disposal stage of the real estate development project, such as residential land development, new construction of buildings, change of usage of environmentally inappropriate buildings.

\section{v. Conclusions}

In this study, the DACUM method was applied to the real estate industry, and as a result, the five tasks consisted of real estate common, real estate brokerage, real estate management, real estate finance and investment, and real estate development. As the responsibilities of each job, there are 7 tasks of real estate general planning, 7 tasks of real estate contract, 4 tasks of real estate management in real estate management, 6 tasks of real estate finance and investment in real estate management In real estate development, it was classified into 6 tasks of real estate supply. After the Task / Skill Matrix was written, major subjects were derived by knowledge $(\mathrm{K})$, function $(\mathrm{S})$, and tool $(\mathrm{T})$. In particular, this study was conducted in the context of the government's prescription educational policy to nurture a specialized college in response to a rapid change in population structure and an absolute decrease in the schooling population. In particular, since the global financial crisis, industries are demanding workforce-oriented manpower that combines theory and on-the-job skills. In this context, a job description and work specification are tailored to the educational goals of cultivating practical- And the basis for course development. In addition, we will identify 
the current status and problems of the qualification system for commercial buildings and suggest ways to improve the efficiency of commercial real estate management, and utilize it as basic data for development of qualification system and real estate market.

\section{References}

[1] C. DuekKuen, "Review on National Competency Standards(NCS) in real estate sector," Appraisal studies, Vol.15, No.2, pp.49-64, 2016.

[2] C. GulSung, "A Study on the Evaluation and Improvement of Building Maintenance System," Korea Institute of Science and Technology collection of dissertations, Vol.12, No.8, pp.3785-3793, 2011

[3] J. JaeHo, "The development direction of the real estate industry and the qualification system: Changing characteristics of the real estate industry and challenges of development," KOREA REAL ESTATE ANALYSIS ASSOCIATION Academic presentation paper collection, Vol.2014, pp.177-202, 2014.

[4] J. SeongHun, "Improvement of real estate related job and qualification system," KOREA REAL ESTATE ANALYSIS ASSOCIATION Academic presentation paper collection, Vol.2014, pp.165-176, 2014.

[5] K. HongJin and K. BongSung, "A Study on Activation of Commercial Real Estate Development," Korea Real Estate Academy review, Vol.44, pp.236-250, 2011

[6] K. JaeUn, "A Study about the legislation of National Certificate of Property Manager," Public land Law Review, Vol.63, pp.141-162, 2013.

[7] K. JaeUn, "A Study about the Qualification Betterment for the Growth of Housing Rental Man-agement," Appraisal studies, Vol.14, No.2, pp.41-57, 2015

[8] The Korean Association of Urban Policies, "Development of National Capability Standards (NCS) and Qualification Improvement Opportunities in the Real Estate Industry - Fields of Commercial Building Management," The Korean Association of Urban Policies Academic con-vention, Vol.2014, No.11, pp.93-100, 2014.

[9] Y. YeoSin, "Current Status and Trends of Commercial Real Estate Market Change and Asset Management," KOREA REAL ESTATE ANALYSIS ASSOCIATION Academic presentation paper collection, Vol.2013, No.1, pp.445-454, 2013.

About Author (s):

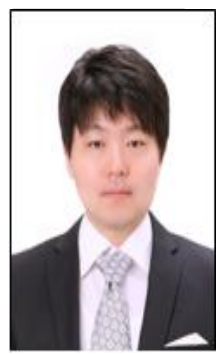

Dr. Jaehwan, Kim

$\mathrm{He}$ is a assistant professor at the Faculty of Regional development (major in Real estate studies), Republic of Korea.

His research interest are mixed use development, feasibility study and decision making methodology on real estate. 